\title{
Delegation of State Powers to Local Self-Government Bodies: Foreign Experience and Ukrainian Realities
}

\author{
Svitlana Serohina \\ Scientific Research Institute of \\ State Building and Local Government of \\ the National Academy of Legal Sciences of Ukraine \\ Chernyshevska 80, \\ Kharkiv 61002, Ukraine \\ E-mail:ndi_db_ms@ukr.net \\ Iryna Bodrova \\ Scientific Research Institute of \\ State Building and Local Government of \\ the National Academy of Legal Sciences of Ukraine \\ Chernyshevska 80, \\ Kharkiv 61002, Ukraine \\ E-mail: irina_bodrova@ukr.net \\ Anna Novak \\ Yaroslav Mudryi National Law University \\ Pushkinska 77, \\ Kharkiv 61024, Ukraine \\ E-mail: anyt@ukr.net
}

Abstract: This article is devoted to the study of the problems of the delegation of state powers to local self-government bodies. The paper reveals the pluralism of approaches to the organization of models of such interaction in the countries where various doctrines of the organization and functioning of local self-government prevail (the state-oriented doctrine, the community-oriented doctrine, and the doctrine of municipal dualism). Using the example of various European states (grouped on the basis of the prevailing doctrines presented above for convenience), we reveal specific schemes for the legal regulation of interaction within such relations, their positive features, and drawbacks. The obtained data presented in a compressed form in the paper also features an in-depth analysis of the 
constitutional and legal regulation of the delegation of state powers to local governments in Ukraine. An important element of the novelty of the study was the projection of modern Ukrainian problems in the field of delegated powers through the prism of the existing European systems and relevant experience, thereby complementing this study with a comparative dimension.

Conclusions made by the authors feature a set of recommendations based on the conducted comparative research and on formal and logical analysis of compliance of the domestic model of the delegation of powers with the provisions of the European Charter of Local Self-Government. Taking into account the fact that European standards in the sphere of the delegation of powers (depends on the adoption of amendments to the Constitution of Ukraine and the Law 'On delegation of separate powers of executive authorities to local self-government bodies') are not yet implemented in Ukraine, we believe that this research will not only be useful in the context of theoretical and scientific research of the issue but also has the potential to contribute to the development and implementation of relevant legislation.

Keywords: decentralization, local government, self-government, state powers, Ukraine

\section{Introduction}

The institute of the delegation of state powers to local self-government, which has been known since Roman law, has over time been adopted as a legal practice in many countries of the world (Novak, 2014). Modern states view it as an important element of the system-functional organization of power, which allows, firstly, to avoid excessive concentration of power at the central level, overloading the central government with local affairs; secondly, to ensure the participation of the population in the exercise of power, in the political process; thirdly, to bring the state power closer to civil society; and fourthly, to rationalize and optimize municipal governance as a whole (Onupriienko, 2009).

At the present stage, the provisions of international law contribute to the development of universal standards in foreign countries in the field of transfer of state powers to the local level. In particular, we are talking about the provision of the European Charter of Local Self-Government, Article 4 of which enshrines 
the right of central or regional authorities to delegate their powers to local selfgovernment bodies, since the latter are in closest contact with citizens. Local self-government bodies have the right to adjust the delegated activity to local conditions to the extent possible (European Charter of Local Self-Government, 1985).

For Ukraine, the problem of delegation of state powers to local self-government bodies has remained topical and important throughout the modern period of state-legal development - from the implementation of the institute of delegated powers as part of the competence of the executive bodies of local councils in the Law of Ukraine 'On local councils of people's deputies and local and regional self-government' in 1990 to draft proposals for its reform in the Draft Law of Ukraine 'On amendments to the Constitution of Ukraine (regarding decentralization)' in 2015 (Law of Ukraine 'On local councils of people's deputies...', 1990; Draft Law of Ukraine 'On amendments to the Constitution of Ukraine', 2015). The systemic reform of the decentralization of power that began in 2014 did not essentially change the existing procedure for the delegation of state powers, but only resulted in an increase in the number of such powers vested in municipal authorities. This has only increased the scientific interest in studying the nature of delegated powers, its compliance with the principles of decentralization of state power and optimization of the national mechanism of the delegation of state powers to municipal governments.

Legal science traditionally pays considerable attention to the issues of regulating the competence of local self-government and its bodies. At the same time, there are practically no comprehensive studies of the delegation of certain powers of executive authorities to local self-government bodies. In this regard, there is an urgent need for an in-depth study of the legal regulation of the implementation by local governments of delegated powers, its comparative legal aspects, the mechanism of implementation by local governments of delegated powers at the present stage and the identification of areas for improving legal regulation within the framework of the reform of decentralization of power.

This article contains the authors' position on the comprehensive renewal of the mechanism of the delegation of powers in Ukraine in its legal, organizational, functional, material and financial aspects, developed on the grounds of comparative legal research and formal and logical analysis of domestic legislation and municipal practice. 


\section{Problematic issues of theory and practice of the implementation of state powers by municipal authorities in foreign countries}

Comparative legal research is becoming increasingly important in the field of state and municipal development. Ukraine, as well as other post-Socialist countries, tries to adopt the model of national-local relations of the developed democracies. At the same time, in the process of implementation of such models, there are many difficulties because blind copying of existing normative models leads to frankly absurd situations (Rechitskiy, 2011). The study of deviations from the classical model of cooperation between the state and the local selfgovernment helps to avoid common mistakes.

The research conducted by the authors was based on the use of a wide range of methods and techniques of comparative legal analysis. The volume of the article unfortunately does not allow to present all the obtained analytical data, but makes it necessary to dwell on the most important aspects, in the authors' opinion, such as generalized description of the mechanism of delegation of powers in a particular group of countries, establishment of positive features, identification of the problems of the mechanism of delegation and ways to overcome them, which is exemplified on the basis of the most illustrative examples of individual states of the respective group.

The research of legal regulation and the order of implementation of delegated powers of local self-government bodies in foreign countries has shown that they are conditioned by the state-chosen and, in most cases, by the constitutionally enshrined doctrine of local self-government-state-oriented, communityoriented, and dualistic. These affect the legal status of local government, its nature (self-governing, state-run, or dualistic), degree of autonomy (absolute, relative, dependent), legal, institutional, political, and other mechanisms of interaction with the state power. Existing municipal-legal doctrines, in essence, are the expression of certain types of legal culture, which are objectively formed in the life of specific societies, and under conditions of pluralistic democracy, these become a matter of political choice.

The mechanism of the delegation of powers experiences the most significant development in the countries, the municipal legal practice of which embodies the doctrine of municipal dualism. These include Italy, Spain, France, Belgium, Poland, the Czech Republic, Slovakia, Bulgaria, Hungary, Finland, the Baltic States, Turkey, etc. After all, it is precisely these conceptual foundations that allow building a consolidated mechanism of public administration on the basis 
of functional specialization of state and municipal bodies. Although recognized as autonomous entities, the municipal authorities act as agents of the state for the implementation of a clearly defined range of state tasks. This approach aims at ensuring equal national standards of quality of life for the population in different regions of the country.

The mechanism of the delegation of state powers to municipal bodies in the states that are adherents of the doctrine of municipal dualism is characterized by the following generalized features: (1) the delegation is carried out on a basis of law, as a rule, on a contractual basis. At the same time, the municipal legal practice of the group of countries studied knows examples of the so-called mandatory delegated state powers, which are few and, typically, apply to such areas as health care, education, economic services (supply of energy and water resources), and licensing of certain types of activities; (2) the delegation of individual state powers to municipal bodies has a subsidiary character and, accordingly, the delegated powers do not and cannot prevail over the powers of their own, self-governing nature; (3) the procedure for exercising the delegated powers is based on the principle of freedom of adaptation to local conditions; (4) municipal bodies are guaranteed appropriate financial resources for the exercise of such powers; and (5) the state supervision of the execution of delegated powers consists, in most cases, in the assessment of the quality of the results of the provision of services to the population. Obviously, the mentioned mechanism of delegation of state powers to municipal bodies to the greatest extent embodies international legal standards provided by the European Charter of Local Self-Government.

At the same time, despite the stability of national practices and the development of the organizational and legal mechanism of delegation of powers, modern states are faced with significant legal, organizational, material and financial problems in this area. The analysis of the national municipal legal practices of the group of countries under study has shown that the most common among them are the following:

Firstly, it is the lack of funding for the delegated powers and, as national scholars emphasize, the lack of connection between the financial basis of the delegated powers and the taxation system of the country (Wytrążek, 2004).

There are various ways in which the states have addressed this problem. For example, in Spain this is overcome by the fact that the state delegates functions and powers only to those municipalities that have significant financial, human, and management capacity, while the system of financial equalization and 
unification of municipalities is used to form powerful municipalities. Poland, on the other hand, has established a system of financial precautionary measures: (1) it is guaranteed by law that the municipality will receive the amount of funding required to carry out the tasks assigned to it by the state (as a rule, such grants account for more than $10 \%$ of the gminas' own income); (2) in case of failure to maintain the terms of state funding, local councils are guaranteed interest accrual at the rate established for tax debt; (3) the transfer of 5\% of the revenues received in connection with the implementation of delegated state tasks to the gminas' own revenues. A different approach has been adopted in the French Republic: the transfer of competence to the regional and municipal levels by the state includes the right of the bodies of territorial collectives to make final decisions and manage the finances independently. In the case of expansion of the transferred competence, the volume of financial resources is increased accordingly. (Constitution of the French Republic, 1958)

Secondly, the exercise of state-delegated powers can sometimes make it difficult for municipalities to exercize their own powers or require them to incur too much financial, infrastructural and other costs. In order to prevent harm to municipal interests, for example, in Spain, the delegation of public powers is only possible with the consent and interest of the municipal council, which, in cases of breach of financial obligations by the state and the inability to exercise its powers effectively, may decide to terminate such powers.

Thirdly, the so-called "alleged" or "non-standard" powers are considered as a serious threat to the balance of the public administration system. In Poland, the former of these are the administrative tasks entrusted to municipal bodies without granting them decision-making powers. "Non-standard" powers, on the other hand, are well known in the Kingdom of Spain: these include the right of municipalities to intervene in any social and economic sector in order to meet the new needs of their citizens or to exercise de facto delegated public powers on an ad hoc basis. The state policy of reducing such powers presupposes the determination of exceptional conditions for their implementation: when the municipalities' own powers are guaranteed to a sufficient extent; when the implementation of "non-standard powers" does not violate budgetary and financial stability (Morata García de la Puerta \& Rosado Rodríguez, 2001).

Fourthly, unitary states have faced the problem of the lack of a uniform legal mechanism for the delegation of powers. This situation is a result of the regionalization carried out by these states, which provides for the granting of the regional authorities the right to adapt the basic national legislation (Local and regional democracy in Spain, 2013). This determines the need to establish 
a range of regulatory requirements to the levels, procedure, and subject of delegation of powers at the level of organic laws while continuing the reforms of administrative and financial decentralization.

And fifthly, the principle of balancing the degree of administrative control over the activities of municipal bodies, in accordance with the importance of the interests that are protected, remains of particular importance. Because, in practice, such control often turns into the supervision of the expediency of municipal activities. To prevent this, in the Spanish Kingdom, it is established that the control activities carried out by the state should be aimed at providing instructions and other methodological clarifications on the implementation of the delegated powers, obtaining information from municipalities at any time on the progress of their implementation, providing recommendations on eliminating deficiencies, appealing against municipal acts, the withdrawal of delegated powers, if necessary, and the replacement of their executor. At the same time, the right to control the expediency, reliability, and efficiency of municipal actions is legalized in Poland. In particular, the voivode may suspend the performance of the assigned state tasks, annul the decision of the municipality, and the Regional Audit Chamber has the right to annul the financial decisions of local governments (Sauer, 2013).

These measures for minimizing the negative aspects of the national mechanisms of the delegation of state powers to local governments are aimed at increasing the transparency and optimization of administrative processes of public management, their further decentralization, and democratization, maintaining the autonomy in the process of implementation of delegated and own powers. For Ukraine, which is on the way to the implementation of the European standards of local self-government, they are of particular interest, as they provide an opportunity to prevent their possible shortcomings at the stage of development of the appropriate organizational and legal mechanisms.

The following two groups of countries can be characterized as those in which the mechanism of delegation of state powers has been less developed, but for different reasons - as a result of the "governmentalizing" of local governments in the conditions of the state-oriented municipal legal doctrine or the autonomization of municipal administration in the conditions of implementation of the community-oriented doctrine.

The state doctrine, which defines local self-governance as a lower level of the executive vertical, focused on the performance of state affairs on a local scale, allows national states to build a centralized model of functioning of the territorial 
organization of power. Delegation of powers is carried out on a mandatory basis, and the exercise of such powers is regulated by unified procedures and procedures ensured by state resources and comprehensive control of central power. These activities acquire the characteristics of "state guardianship". Under this approach, the wide range of functions and tasks assigned to local self-government bodies leads to the actual "governmentalizing" of these bodies, because the state powers become dominant in the structure of municipal competence.

Until the 1990s, the state-oriented doctrine dominated many countries of the so-called "Socialist camp". Today it is mainly represented in the constitutional legislation of the post-Soviet republics (the Russian Federation, the Republic of Belarus, the Republic of Armenia, the Republic of Kazakhstan, the Republic of Uzbekistan, etc.), the People's Republic of China, the Democratic People's Republic of Korea, and some other states. The study of the practice of redistribution of powers by these states to the local level is seen as extremely important from the point of view that having practically identical "exiting" conditions and problems with other post-Soviet countries in the sphere of state-building, by choosing a different, euro-integration vector of municipal development, Ukraine should clearly understand the risks and tendencies of "governmentalizing" of local self-government in order to prevent them in advance. And this task does not lose its significance for our country even today. In fact, despite the fact that according to the Law of Ukraine 'On local self-government in Ukraine' the share of state-delegated powers amounts to $48 \%$ of the total amount of powers of municipal authorities, in reality, their number is significantly increased by sectoral laws, which in turn creates the risks of governmentalizing of local governments. In addition, Ukraine retains an exclusively mandatory, statutory way of delegating powers.

Among the general features of the mechanism of the delegation of powers inherent in countries with a state doctrine of local self-government, based on a summary of national legal and implementation practices, the following can be highlighted: (1) state powers are delegated on a mandatory basis by law, without setting clear boundaries for such delegation. Such boundaries may not be provided for at all or may be open-ended; (2) the procedure for exercizing the delegated powers is regulated, generally, by by-laws and regulations and does not provide for its adaptation to local conditions and needs of the local community; (3) the legislation does not stipulate special procedures of interaction between executive power bodies and local self-government bodies on the issues of delegated powers; (4) material and financial support for the delegated powers is provided within the general budgetary framework; and (5) 
the control over the execution of delegated powers by local self-government bodies is usually not regulated at the legislative level and is characterized by the breadth of its subject matter, forms, controlling subjects, and procedures. The systemic problems of this mechanism should include: (1) the lack of elaboration of a comprehensive concept of local governance, which should be based on the criterion of efficiency of functions and powers; (2) the overload of municipal bodies with state powers, which leads to a decrease in the efficiency of the implementation of their own powers and reduce the quality of municipal services; (3) the lack of a clear funding system for the delegated powers; (4) the lack of development of mechanisms necessary for the implementation of the delegated state powers. The solution to these problems is associated with an attempt to democratize the procedure of the delegation of powers, but at the same time preserving the patronage function of the state in relation to local selfgovernment.

In the countries that have implemented the ideas of the "community-based" doctrine of local self-government (Portugal, Great Britain, USA, Canada, Australia, New Zealand, etc.) in their political and legal practice, local collectives have historically received a high degree of autonomy from the state in the field of local affairs. The state deprived itself of the right to interfere in this process. Cases of such interference are isolated and considered an exception to the general rule. The spheres of competence of the state and municipal authorities are, generally, strictly separated and clearly delineated, and therefore the delegation of state powers does not take on the same importance as in other countries.

A normatively established, precise, and concrete distribution of powers among public authorities eliminates the need for delegation of powers. The delegation may not only be absent as a phenomenon but may even be outlawed, as is the case in Portugal. Article 111 of the Constitution of this state expressly prohibits public authorities, autonomous regions or local administrations from delegating their powers to other bodies, except in cases and within the limits directly provided for by the Constitution and the law (Constitution of the Portuguese Republic, 2005). At the same time, the necessity of establishing a mechanism of interaction between public authorities and municipalities is undeniable. The state provides the necessary and sufficient legal basis for this and undertakes to promote the development of forms of such cooperation. Since, as noted, for example, in Part III 'Equalization of opportunities and regional inequalities' of the Constitutional Act of Canada 1982 (Art. 36), it is aimed at ensuring equal opportunities for all citizens in their pursuit of well-being and economic development and the provision of quality services to them carried out by basic public services (Consolidation of Constitution Acts, 2012). 
The forms of interaction between the state bodies and municipalities can include: (1) general programs of activity implemented by the state, regional bodies and municipalities on a contractual basis; (2) provision of technical support and human resources to local authorities with strict observance of their autonomy; (3) participation in the implementation of national or regional development programs of a certain territory. At the same time, the content of these forms of interaction effectively provides for the voluntary acquisition of additional powers by the municipalities. In Portugal, Law no. 159/99 establishes that the transfer of powers depends on the level of significance of the tasks and competence: (a) the transfer of powers that fall within the competence of local authorities is carried out on the basis of the rules adopted by these authorities (transfer from municipalities to parishes); (b) the transfer of powers provided for in the regional programs is possible after consultation with the coordinating commissions of administrative regions (transfer from administrative regions to municipalities or parishes); (c) the transfer of powers within the framework of the implementation of national programs is carried out on the basis of priorities established by the Parliament at the proposal of the Government (Law of the Portuguese Republic 'Transfer of tasks and powers to local authorities', 1999).

At the same time, the group of countries under study recognizes that today's de jure state-municipal relations are not able to sufficiently supply communities with the necessary powers and financial resources to provide quality services to the population.

At that, several major problems are highlighted. First, the unwillingness of municipalities to take on additional state tasks due to the lack of territorial, demographic, financial and administrative resources. To address this problem, efforts are being directed towards: (1) the formation of powerful inter-municipal entities, which are able to implement most of the public services, ensure interaction between municipalities and government agencies and achieve goals that are of common interest to the population of these inter-municipal entities; (2) the increase of state subsidies in such spheres as education, health care, social integration, culture, etc. (Decentralization of competences, 2014); (3) the provision of technical support for structural reforms of self-governing units' authorities (Restructuring Program for the State's Central Administration, 2006).

Second, the need to ensure balanced development and financial equalization of different regions became a serious problem. As a result, Portugal, for example, adopted the Law no. 2/2007, which, essentially, legalized the state's interference in the formation and distribution of local finances: the Law establishes the obligation of municipalities to develop their financial policies in accordance 
with the National Programme for Stability and Growth and the State Budget through the Financial Coordination Council created by the Government (Art. 5) (Local Finance Law, 2007). In this regard, one cannot but agree with the experts' assessment that this Law creates a new model of relations between the state and local institutions, which provides for the introduction of the institute of delegated state powers (European Council, 2007).

Thus, the institute of delegation to local self-government bodies is not only well recognized by the state and legal practice of modern states but also characterized by a significant diversity of national mechanisms of its implementation. Reflecting the basic regularities of state development and ensuring adequate distribution of powers between the executive authorities and local selfgovernment bodies in certain political, socio-economic and other conditions, it is constantly undergoing transformation. The above generalized information on the national mechanisms of delegation of state powers provides an idea on the most established and common approaches, forms and methods of the delegation. However, the conclusions about the expediency of their transfer to the domestic state-legal spheres can be made only after the analysis of the current Ukrainian model of legal regulation and implementation of state-delegated powers.

\section{Problems of the implementation of European standards in the field of the delegation of state powers to local self-governments in Ukraine}

During the years of sovereign state-building Ukraine has made its way from the state-oriented to the community-oriented municipal legal doctrine, having defined in Article 140 of the Constitution of Ukraine 'self-government' as the right of a territorial community to independently solve the issues of local importance within the limits of the Constitution and laws of Ukraine. Nevertheless, the mechanism of delegation of the separate powers of executive power bodies to local self-government bodies has hardly changed.

The existing system of delegated powers of local self-government bodies was formed in the conditions of strict centralization of power at the local level. Taking into account the instability of the political system and the weakness of the economic foundation, the legislator tried to simultaneously guarantee the autonomy of local self-government and maintain the balance and efficiency of the system of governance at the local level. Nowadays it appears outdated, cumbersome and rigid. Therefore, the redistribution of state and municipal 
powers with the strengthening of the functional role of local governments in the issues of territorial development, livelihoods, provision of public services with adequate material and financial support was the key task of the system reform of decentralization of power launched in 2014.

However, the decentralization of power should be implemented through the establishment or transfer of powers to local self-government bodies, which would effectively lead to their municipalization. However, it is mainly provided by the delegation of powers, whereby the nature of powers remains state-owned. Such an approach, in our view, is a conceptual collision of legal policy. Its solution, in the authors' opinion, is to use the experience of modern states in the constitutional consolidation of the dualistic municipal-legal doctrine. At the highest legislative level, it is necessary to recognize the ability of local selfgovernment bodies to solve both issues of local importance and to participate in the resolution of public affairs through the execution of delegated powers.

In accordance with this, the existing mechanism of the delegation of state powers to local self-government bodies also demands modernization. Nowadays there is a clear understanding that the basis for it should be the provisions of the European Charter of Local Self-Government as such, which embody the best approaches and practices developed and tested by the European states in this field. However, this process is very slow, which is emphasized by the European experts.

In this regard, based on the formal legal analysis of the norms of the European Charter of Local Self-Government and the legislation of Ukraine on local selfgovernment, as well as the formal and logical analysis of the domestic practice of municipal development and its compliance with regulatory requirements, we believe it necessary to identify the main problems of the implementation of the European standards in the field of study.

Firstly, it should be noted that the European Charter uses the notion of 'delegation of powers', the diversity of models of which is allowed at the national level (Part 5 of Article 4).

In Ukraine, the institute of the delegation of state powers to local selfgovernment bodies is of constitutional nature. The Basic Law of the State not only establishes the possibility of granting separate powers of executive authorities to local self-government bodies but also defines its method (by law); in the most general form - the subject of such powers (local self-government bodies), state guarantees of full financial support of such powers and its sources; and establishes the principle of accountability of municipal bodies of executive authority in the exercise of such powers. 
Secondly, the European Charter provides for the possibility of providing local self-government bodies with powers and functions for special purposes in accordance with the Law (Part 1, Article 4). In the practice of foreign states, as we have seen, this is reflected in the application of mechanisms of voluntary and mandatory delegation, that is, the redistribution of powers on the basis of agreements and laws.

The Law 'On local self-government in Ukraine' defines delegated powers as the powers of executive authorities granted to local self-government bodies by legislation. Thus, the legislator not only narrowed the understanding of delegated powers but also stipulated the legal and organizational specifics of such powers (Law of Ukraine 'On local self-government in Ukraine', 1997). The specifics lie in the fact that:

1) Being in nature the powers of the executive authorities, the delegated powers are granted by the legislative body and addressed to an abstract group of municipal subjects. Incidentally, the European experts also focus on this problem of uncertainty of the delegate and the unclear definition of the subject who receives the delegated powers existing in the domestic legislation;

2) The delegation of powers is mandatory, which excludes optionality and voluntariness. After all, failure to comply with the law cannot be justified, even if its implementation contradicts the interests of the territorial community, violates the rights of municipal subjects, as this would violate the principle of legality (Liubchenko, 2006);

3) The delegation is carried out on a permanent basis, and therefore the term of the obligation of municipal authorities to perform such powers is openended.

The current legislative procedure for delegating separate powers of executive authorities to local self-government bodies, which are faced with the task of building a clear, hierarchical organization of public administration, is also cumbersome and inefficient. It is the least able to ensure that public authorities take into account local conditions for the exercise of such powers and the prompt resolution of a particular administrative problem. In this regard, it is extremely beneficial to introduce mandatory (legislative) and voluntary (contractual) types of delegated powers, which will allow liberalizing the existing method of the delegation of powers. At the same time, it should be extremely useful to use the practice of foreign countries regarding preliminary consultations with local self-government bodies when dealing with the issues of mandatory delegation of powers. 
Thirdly, Part 5 of Article 4 of the European Charter defines the delegation of powers as an optional and additional way of establishing the competence of local self-government. This means that the delegated powers should not be dominant in the structure of competence of municipal bodies and should not prevail over their own powers.

In Ukraine, however, the situation is quite different, as described above. There is a tendency to constantly increase the volume of delegated rather than own powers of local self-government bodies since the redistribution of competence between central and local executive authorities and local self-government bodies within the framework of the power decentralization reform is provided specifically by delegation.

Such a balance of own and delegated powers in the structure of competence of municipal bodies does not correspond to the provisions of the Constitution of Ukraine, which provide for the possibility of granting local self-government bodies only separate powers of executive authorities. That is, the scope of delegated powers cannot be excessive. Otherwise, the "state-ization" (governamentalization) of local self-government will inevitably take place. As noted by researchers, if the share of state powers in the total volume of tasks of local self-government bodies exceeds 50 percent, a contradiction arises between the municipal status of local authorities and the state nature of their basic powers (Berg, 2003). Under such conditions, almost all ministries, central and local executive authorities use local self-government bodies as their territorial bodies. As a result, the entire system of executive bodies of local councils is involved in the process of implementing the powers of executive bodies, and this gives grounds to characterize them to a greater extent as state authorities, rather than executive bodies of local councils (Liubchenko, 2005).

Researchers see a solution to this problem in transferring a significant number of delegated powers to the local self-government own competence (Pohorilko \& Baimuratov, 2009). Supporting the idea of the revision of the scope of own and delegated powers, we are convinced that such revision should not be mechanical and should not lead to deterioration of the state of management at the local level, unjustified increase in the administrative and financial burden on the local self-government system. It should address the redistribution of powers not so much in terms of quantity as in terms of quality, taking into account the socioeconomic, infrastructural, managerial, resource and other potential of local selfgovernment bodies. 
Fourthly, from the point of view of the European Charter, the subject of the delegation may be a clearly defined body at both the national and regional levels of the territorial organization of public power.

In Ukraine, the model used by the legislator to "grant delegated powers by legislation" deprives them of their authority. Being, in essence, the powers of executive authorities, they are delegated by the Parliament, which, functioning on the principles of separation of state power, actually solves the issues of distribution of competence on the vertical of public administration both within the system of executive authorities and outside of it. Such a procedure deprives of the possibility to clearly establish the primary bearer of powers delegated, and, accordingly, the subject of departmental control over the execution of such powers.

Fifthly, when delegating powers to local self-government bodies, the European Charter guarantees the right of local self-government bodies to adapt their activities to local conditions as closely as possible. Such a possibility corresponds not only to the principles of local self-government but also to the very method of the redistribution of power. In addition, taking into account the fact that the adaptation of the authoritative activity on the implementation of delegated powers can be carried out in different legal forms, this provision of the European Charter actually proceeds from the possibility of implementing municipal regulation of relevant relations.

The problem of the municipal level of legal regulation of the implementation of delegated powers in Ukraine is extremely relevant today. After all, municipal practice has overtaken the legislative regulation by adopting various acts in this area: in particular, the decisions of local councils determine the system of executive bodies performing the delegated powers, divide the powers between them, approve the number of employees, and establish the order of use of state property objects transferred to ensure the execution of delegated powers. Other issues of spending of public finances provided for the implementation of delegated powers are solved and the decisions of executive bodies of local councils determine the individual issues of implementation of particular delegated powers of organizational and procedural nature. That is why there is a need to formalize not only the competence of municipal bodies but also the administrative procedures for exercising authorities within this competence (Shcherba, 2009). At the same time, the question of the degree of legal independence becomes important. It is of limited nature - municipal regulation should be carried out within the limits of powers and in the manner provided by the legislation of Ukraine. 
The need to introduce contractual arrangements for the delegation of authority is particularly important. This procedure will allow for the fullest implementation of the abovementioned requirements of the European Charter. The need for contractual regulation of the delegation of powers has been repeatedly voiced in scientific circles. Supporting this idea, we believe that the essential and necessary conditions for such delegation are: the purpose of the delegation, a specific list of powers, the term of their execution, the subjects of delegated powers, mutual obligations of the parties, the order and scope of material, financial, informational and other support of the execution of delegated powers, the forms and procedure of control over the execution, the grounds and procedure of liability of the parties for failure to perform or improper performance of the contract, the grounds and procedure for termination of the contract. The widespread practice of concluding such contracts will make the institute of the delegation of powers more mobile and dynamic, giving the latter signs of temporality.

Sixthly, from the point of view of the guarantees of the sustainability of local self-government as defined in Article 9 of the European Charter of Local SelfGovernment and the proportionality of powers and material and financial resources of its bodies, an emphasis is placed on the material and financial support of the delegated powers.

The Constitution of Ukraine guarantees full material and financial support by the state for the implementation by local self-government bodies of the powers delegated to them by the executive authorities. There are three ways of providing these: (1) direct financing at the expense of the state budget of Ukraine; (2) redirection of certain state taxes to local budgets in accordance with the procedure established by law; (3) the transfer of state property to local self-government bodies. The effectiveness of these methods varies and the prevalent among these are targeted subventions from the state budget (aimed at the implementation of state social protection programs, educational, medical subventions, subventions for investment projects, and others).

The analysis of local budget data as a whole shows a gradual increase in the volume of transfers from the state budget of Ukraine, but at the same time their significant drawbacks start to show, such as the disregard of inflationary processes, changes in the system of institutions and the circle of persons serviced by them (opening of new institutions, servicing of temporarily displaced persons), the focus on the actual indicators of the previous budget period. As a result, targeted subventions do not cover actual expenditures. However, this does not deprive local self-government bodies of the obligation 
to perform the delegated authorities. We are convinced that, in this matter, the rights and legitimate interests of local self-government should be ensured by guarantees of legal protection, including judicial protection. Thus, it is advisable to introduce the practice of some of the European states on the right of a local self-government body to terminate the execution of the delegated powers of the state in case of failure or improper performance of the state obligations on their material and financial support, as well as in case of the inability to effectively exercize their own (self-governing) powers.

As previously noted, the issue of adequate material and financial support is a critical one for almost all the states, and the experience of recent years shows that it cannot be resolved solely by financial measures. It requires a systemic public policy, ranging from the promotion of financially powerful municipalities and the expansion of inter-municipal cooperation to the updating of fiscal policy.

Seventhly, achieving the goals and objectives of the delegation of individual state powers to municipal authorities is possible only with an effective system of control. Therefore, control from the point of view of the standards established by the European Charter is a necessary element of the mechanism of the delegation of powers and it is subject to the requirements of Article 8 of the said European Act.

From the point of view of the European standards, it is worth noting that the European Charter does not refer to control, but rather to supervision. However, based on the national traditions of the state, supervision is considered as one of the forms of control activities, which has a narrower scope of application. Therefore, in the Ukrainian legislation, there is a tendency to replace the term 'supervision' with the term 'control' and not vice versa.

The main forms of state control over the exercise of delegated powers by municipal bodies of executive power in Ukraine are recognized as (1) analyzing the acts of local self-government bodies; (2) obtaining information provided by municipal bodies on the performance of delegated powers; (3) conducting audits of the activities of executive bodies of local councils. These activities are carried out by regional bodies of executive power (state administrations), as well as territorial bodies of ministries and other central bodies of executive power.

To date, the status of legal regulation of state control over the implementation of delegated powers by local governments in Ukraine is characterized by different levels of variability and fragmentation, system of subjects - by redundancy and low consistency, and the organizational mechanism is more indicative of the implementation of monitoring than real control measures of impact. The 
solution of these problems requires the provision of its proper legal basis, improvement of forms of control activity, determination of the type and limits of responsibility of local self-government bodies for non-execution or improper execution of delegated powers.

The solution of these and other problems determine the need, primarily, for substantial modernization of constitutional regulation of both the institution of delegated powers and local self-government as a whole. The Draft Law of Ukraine 'On amendments to the Constitution of Ukraine (regarding decentralization of power)' was to be aimed at this purpose. Among other things, the Draft Law proposed to clarify (a) the way of expanding the competence of local self-government bodies (by delegating to them certain powers of executive authorities); (b) the range of local self-government bodies to which certain powers of executive power bodies (executive bodies of local self-government of the community, executive committees of the district, regional council) may be delegated; (c) levels of territorial organization of power at which the mechanism of delegation can be applied (community, district, region), the sources of material and financial support by the state for the exercise of the delegated powers by local self-governments, as well as the range of executive authorities controlling the exercise of such powers. In addition, a mechanism for the withdrawal of the delegated powers was introduced. However, the incompleteness of the constitutional reform on decentralization of power has indefinitely "preserved" the existing legal problems of the delegation of state powers to local governments in Ukraine.

\section{Conclusions}

Summing up the results of the research, we believe it necessary to note the following. If the delegation of state powers to municipal bodies as a whole is a universal form of interaction between the state and local self-government, its content and order are not so universal. Each state has its own organizational and legal features and related positive traits and problematic aspects of delegation. The conducted comparative legal analysis showed that the introduction of a certain model of delegation of state powers to municipal authorities is in direct dependence with the adoption of a particular municipal-legal doctrine.

In countries where the model of local governance has been developed in accordance with the doctrine of municipal dualism, the delegation of state powers is intended to involve municipal authorities as agents of the state in 
a well-defined range of tasks. The exercise of the delegated powers is based on the principle of freedom to adapt to the local conditions, which entitles the municipal authority to require the state to allocate financial resources for the development of its own management capabilities and to refuse to perform such powers if they are underfunded. The government's participation in this process is to assess the quality of the results of the provision of services to the population transferred to municipal authorities.

In the states whose constitutional legislation has adopted the state-oriented doctrine, the delegation of state powers to municipal bodies is an element of the state mechanism for the implementation of state power in the field. Overburdened with mandatory delegated state powers, constantly being under tight administrative control over their implementation, combined with the lack of funding leads to the loss of representative nature of municipalities and reduced efficiency in the performance of their powers.

In the countries where the system of local self-government is traditionally built on the basis of the community-oriented doctrine, the mandatory delegation of powers is least common for municipal authorities. At the same time, these bodies participate in the implementation of national programs through various forms of social partnership based on voluntary and mutually beneficial agreements in order to ensure proper socio-economic development of communities.

The current Ukrainian model of the delegation of state powers to local selfgovernance bodies, formed under the conditions of centralized management at the local level is outdated, slow-moving, cumbersome, and does not comply with the standards established by the European Charter of Local Self-Government. Its modernization requires a comprehensive approach - from the consolidation of legal doctrine of municipal dualism at the constitutional level to the provision of local self-government bodies with legal autonomy in the adjustment of the execution of delegated powers to local conditions.

The conducted research allows addressing those forms and methods of the delegation introduced in foreign countries, the adoption of which in the domestic public-legal practice will have a significant positive impact on the democratization of this process, enabling the promotion of the most comprehensive implementation of international standards. Thus, we consider the following practices of foreign countries to be promising areas of national reform: (1) the introduction of mandatory (legislative) and voluntary (contractual) delegation of powers; (2) the conduct of preliminary consultations with the local self-government bodies of the respective communities by the state 
authorities when deciding on the issues of mandatory delegation of powers; (3) the strengthening of state guarantees to ensure the implementation of delegated powers. Voluntary delegation should be carried out with the consent and interest of the representative body of local self-government of the community concerned. To provide a representative body of local self-government with the right to make a decision on termination of the execution of the delegated state powers in case of non-fulfillment or improper fulfillment of the state obligations on their material and financial support, as well as in case of the impossibility to effectively carry out their own (self-governing) powers; (4) to introduce the principle of freedom to adapt the powers delegated by the state to local conditions; (5) to establish the additional guarantees of material and financial support of delegated powers, in particular, to ensure the accrual of interest at the rate established for tax debt in case of violation of the terms of public funding; a fixed percentage of the income received from the implementation of the delegated tasks should go to the budgets of the respective communities; (6) the delegation of powers should be based on the criterion of the effectiveness of its implementation; (7) to facilitate the formation of powerful municipalities by means of a system of financial equalization, unification of municipalities, formation of inter-municipal entities, implementation of inter-municipal cooperation, state support of structural reforms of local self-government bodies; and (8) to clearly define the forms and boundaries of state control and legal responsibility of municipal authorities for failure to perform or improper performance of delegated powers.

The implementation of these guidelines should be based on the proper legal framework, which should be provided by the laws of Ukraine 'On amendments to the Constitution of Ukraine (regarding the decentralization of power)' and 'On the delegation of certain powers of executive authorities to local selfgovernment bodies'.

Prof. Svitlana Serohina, LLD, is director of the Scientific Research Institute of State-Building and Local Government of the National Academy of Legal Sciences of Ukraine, head of the Department of State-Building of Yaroslav Mudryi National Law University, and associate member of the National Academy of Legal Sciences of Ukraine. Prof. Svitlana Serohina is a Member of the Constitutional Commission established by the President of Ukraine in 2015, a member of the Working Group on Improving the Territorial Organization of Power and Local Self-Government of the Ministry of Regional Development, Construction, Housing and Municipal Services of Ukraine; she is head of the Commission on Administrative and Territorial System and Local Self-Government. She is involved in the examination of regulatory acts and works as a member of working groups on the development and improvement of the legal basis of local self-government. She has authored more than 
150 scientific works. Her working areas are the constitutional and legal aspects of the decentralization of public authority, territorial organization of public authority and local selfgovernment.

Iryna Bodrova, Candidate of Legal Sciences, is vice director of the Scientific Research Institute of State Building and Local Government. Iryna Bodrova is head of the research project in the area of the reforms of local self-government and territorial organization of power in Ukraine in the framework of the Council of Europe support to Ukraine-provided within Immediate measure package for Ukraine and the Council of Europe Action Plan for Ukraine through the Programme 'Strengthening the capacity of local authorities in Ukraine'. She also is a member of the working groups of the Constitutional Commission of the Regional Department of the Ministry of Justice. She is involved in the examination of regulatory acts and works as a member of working groups on the development and improvement of the legal basis of territorial organization of power, participated in the development of National Strategy of reforming of the territorial system of organization of power in Ukraine. She has authored more than 100 scientific works. Her research interests include the legal aspects of the local government, decentralization of power, territorial organization of power, administrative and territorial structure, constitutional and municipal law.

Anna Novak, Candidate of Legal Sciences, is associate professor of the Department of State-Building of Yaroslav Mudryi National Law University. She has authored more than 30 scientific works. Anna Novak's research interests include the constitutional and legal aspects of the local government, decentralization of public authority, territorial organization of power, Ukrainian and foreign constitutional and municipal law.

\section{References}

'As to the compliance...' (2010), 'Shchodo vidpovidnosti natsionalnoho zakonodavstva Ukrainy polozhenniam Yevropeiskoi khartii mistsevoho samovriaduvannia: ekspertnyi vysnovok, pidhotovleno Dyrektoratom z pytan demokratychnykh instytutiv Heneralnoho dyrektoratu z pytan demokratii ta politychnykh sprav Rady Yevropy' [As to the compliance of the national legislation of Ukraine with the provisions of the European Charter of Local Self-Government: an expert opinion, prepared by the Directorate of Democratic Institutions of the Directorate General for Democracy and Political Affairs of the Council of Europe], 30.7.2010. Retrieved from http:/www.slg-coe.org.ua/wp-content/uploads/2012/10/Висновок-Р€щодо-відповідності-національного-законодавства-України-положення.pdf [accessed 15 Apr 2019] 
Berg, O. V. (2003), 'Sovershenstvovaniye vzaimodeystviya gosudarstvennoy vlasti i mestnogo samoupravleniya $v$ Rossii' [Improving the interaction of state and local government in Russia], Gosudarstvennaya vlast' $i$ mestnoye samoupravleniye, no. 5, pp. 17-21.

Consolidation of Constitution Acts 1867 to 1982, prep. by Department of Justice Canada (2012). no. YX1-1/2012. Retrieved from http://laws-lois.justice.gc.ca/PDF/ CONST_E.pdf [accessed 15 Apr 2019]

Constitution of the French Republic (1958), Constitution de la République Française, 4.10.1958. Retrieved from http://www.assemblee-nationale.fr/connaissance/ constitution_01-2015.pdf [accessed 15 Apr 2019]

Constitution of the Portuguese Republic (2005), Constituição da República Portuguesa, 12.8.2005. Retrieved from https://www.parlamento.pt/Legislacao/Documents/ constpt2005.pdf [accessed 15 Apr 2019]

Constitution of Ukraine (1996), Konstitucia Ukrainy, 28.6.1996. Retrieved from http:// zakon2.rada.gov.ua/laws/show/254к/96-вр [accessed 15 Apr 2019]

Decentralization of Competences: Preliminary Draft Decree-Law (2014), 'Descentralização de competências: Anteprojeto de Decreto-Lei. Dossier Municipalização. 2014. Retrieved from http://www.fenprof.pt/Download/ FENPROF/SM_Doc/Mid_115/Doc_9133/Anexos/Anteprojeto_de_Decreto_ Lei_-_descentralizacao_de_competencias1.pdf [accessed 9 Sep 2019]

Draft Law of Ukraine 'On amendments to the Constitution of Ukraine (Regarding to decentralization of power)', Pro vnesennia zmin do Konstytutsii Ukrainy (shchodo detsentralizatsii vlady), proekt Zakonu Ukrainy, no. 2679-VIII, 1.7.2015. Retrieved from http://w1.c1.rada.gov.ua/pls/zweb2/webproc4_1?pf3511=55812 [accessed 15 Apr 2019]

European Charter of Local Self-Government (1985), Yevropeyska khartiya mistsevoho samovryaduvannya, no. 994_036, 15.10.1985. Retrieved from http://zakon2.rada. gov.ua/laws/show/ 994_036 [accessed 15 Apr 2019]

European Council (2007), Local Authority Competence in Europe, Study of the European Committee on Local and Regional Democracy, European Practice Reports, Council of Europe, 8.9.2007. Retrieved from https://wcd.coe.int/ViewDoc.jsp?p=\&id=204 $1471 \&$ Site $=\&$ direct $=$ true [accessed 9 Sep 2019]

Law of the Portuguese Republic 'Legal framework for local authorities' (2013), Regime jurídico das autarquias locais, Lei da República Portuguesa, 12.9.2013. Retrieved from https://dre.pt/application/conteudo/500023 [accessed 15 Apr 2019]

Law of the Portuguese Republic 'Local Finance Law' (2007), Lei das Finanças Locais, Lei Diário da República Portuguesa, 15.1.2007. Retrieved from https://dre.pt/ application/conteudo/522789 [accessed 15 Apr 2019]

Law of the Portuguese Republic 'Transfer of tasks and powers to local authorities' (1999), Republic Transferência de atribuições e competências para as autarquias 
locais, Lei da República Portuguesa, 14.9.1999. Retrieved from http://www. idesporto.pt/ficheiros/file/Lei_159_1999.pdf [accessed 15 Apr 2019]

Law of Ukraine 'On local councils of people's deputies and local and regional selfgovernment' (1990), Pro mistsevi Rady narodnykh deputativ ta mistseve $i$ rehionalne samovriaduvannia, no. 533-XII, 7.12.1990. Retrieved from https:// zakon.rada.gov.ua/laws/show/533-12 [accessed 9 Sep 2019]

Law of Ukraine ‘On local self-government of Ukraine'(1997), Zakon Ukrainy Pro Mistseve Samovryaduvannia v Ukraini, 280/97BP, 21.5.1997. Retrieved from https://zakon. rada.gov.ua/laws/show/280/97-\%D0\%B2\%D1\%80 [accessed on 9 Sep 2019]

Lidstone, D. (2004), Assessment of the Municipal Acts of the Provinces and Territories, Vancouver: Federation of Canadian Municipalities. Retrieved from https:// www.fcm.ca/Documents/reports/Assessment_of_the_Municipal_Acts_of_the Provinces_and_Territories_EN.pdf [accessed 15 Apr 2019]

Liubchenko, P. M. (2005), 'Porivnialnyi analiz konstytutsiinoho rehuliuvannia mistsevoho samovriaduvannia $\mathrm{v}$ Ukraini ta inshykh krainakh' [Comparative analysis of constitutional regulation of local self-government in Ukraine and other countries], Mistseve samovriaduvannia v umovakh demokratychnoi derzhavy, pp. 64-82.

Liubchenko, P. M. (2006), Konstytutsiino-pravovi osnovy rozvytku mistsevoho samovriaduvannia yak instytutu hromadianskoho suspilstva: monohrafia [Constitutional and legal bases of development of local self-government as a civil society institution: monograph], Kharkiv: Odisei.

Liubchenko, P. M. (2008), Mistseve samovriaduvannia v systemi instytutiv hromadskoho suspilstva: konstytutsiino-pravovyi aspect [Local government in the system of institutes of civil society: the constitutional and legal aspect], Synopsis of JCD thesis.

Local and regional democracy in Spain: Recommendation 336, (2013), CG (24)6FINAL, Rapporteurs Marc Cools, Leen Verbeek, Strasbourg, 19-21 March 2013. Retrieved from https://wcd.coe.int/ViewDoc.jpp?p=\&id=2041471\&Site=\&direct=true [accessed 9 Sep 2019]

Morata García de la Puerta, B. \& Rosado Rodríguez, E. (2001), 'Democracy and local government in Spain: Evolution and trends in the interpretation of local autonomy', ECPR Joint Sessions of Workshops. https:/lecpr.eu/Filestore/PaperProposal/ fff19d84-8267-42f6-97d4-488dad4dfc7d.pdf [accessed 15 Apr 2019]

Novak, A. O. (2014), 'Porivnialno-pravovyi analiz delehuvannia povnovazhen orhaniv vykonavchoi vlady orhanam mistsevoho samovriaduvannia v Ukraini ta $\mathrm{v}$ krainakh-chlenakh YeS' [Comparative legal analysis of delegation of powers of executive authorities to local self-government bodies in Ukraine and in EU member states], Teoriia i praktyka pravoznavstva, vol. 2(6). Retrieved from http:// tlaw.nlu.edu.ua/збірник-тппр-№2-2014p/ [accessed 9 Sep 2019] 
Onupriienko, A. M. (2009), 'Delehuvannia derzhavnykh povnovazhen mistsevym orhanam vlady: svitovyi dosvid' [Delegation of state authority to local authorities: world experience], Problemy zakonnosti, no. 102. pp. 28-35.

Pohorilko, V. F. \& Baimuratov, M. O., eds. (2009), Munitsypalne pravo Ukrainy: pidruchnyk [Municipal Law of Ukraine: A Textbook], Kyiv: Pravova yednist.

Rechitskiy, V. V. (2011), 'Prostyye tsennosti konstitutsionalizma: svoboda, rynok i sotsial'naya dinamika' [Simple values of constitutionalism: freedom, market and social dynamics], Konstitutsionnoye i munitsipal'noye pravo, no. 2, pp. 64-69.

Restructuring Program for the State's Central Administration: Final Report, (2006) 'Programa de Reestruturação da Administração Central do Estado: Relatório Final', Comissão Técnica do Prace. Descentralização, Anexo 4. Retrieved from http:// repositorio.ul.pt/bitstream/10451/6291/34/ulsd062670_td_anexo_3_PRACE_5. pdf [accessed 9 Sep 2019]

Sauer, A. (2013), The System of the Local Self-Governments in Poland, Association for International Affairs Research Paper, no. 6. Retrieved from https://www.amo.cz/ wp-content/uploads/2015/11/amocz-RP-2013-6.pdf [accessed 9 Sep 2019]

Shcherba, A. V. (2009), 'Pravove rehuliuvannia administratyvnykh protsedur orhaniv mistsevoho samovriaduvannia' [Legal regulation of administrative procedures of local self-government bodies], Aktualni problemy derzhavnoho upravlinnia, no. 1, pp. 506-511. Retrieved from http://nbuv.gov.ua/UJRN/ apdy_2009_1_67 [accessed 9 Sep 2019]

Wytrążek, W. (2004), 'Decentralizacja administracji publicznej' [Decentralization of public administration], Roczniki Nauk Prawnych KUL. Retrieved from https:// www.kul.pl/files/42/Decentralizacja.pdf [accessed 15 Apr 2019] 